Check for updates

Kent

Cite this as: $B M J 2022 ; 376: 0208$ http://dx.doi.org/10.1136/bmj.0208 Published: 25 January 2022

\title{
Covid-19: Be realistic about elective recovery plan, say leaders
}

\section{Jacqui Wise}

An apparent row over targets is further delaying publication of the recovery plan for elective care, amid calls for the government to be realistic, given the scale of the backlog and the continuing high incidence of omicron infections.

Almost six million people are on a hospital waiting list in England, of whom 312665 were waiting more than a year and 1225 more than two years by the end of October. ${ }^{1}$ The recovery plan was due to be published in December but was initially delayed when the omicron wave struck and threatened to overwhelm the NHS.

The Guardian reported that the Treasury is said to be frustrated with NHS England and privately believes it is "foot dragging" over targets. ${ }^{2}$ A source told the newspaper that the Treasury was keen to set tough targets, while NHS England was calling for more realistic targets because of the current pressures facing the NHS.

Sarah Scobie, deputy director of the health think tank the Nuffield Trust, told The BMJ, "We have observed before that there is always a strong temptation for politicians who are facing difficult news to promise the unachievable in terms of targets in ways they might later regret. We have seen this previously with GP targets and mental health targets.

"The NHS went into the pandemic with demand outstripping capacity and waiting lists already going up. The government needs to be realistic, given the scale of the backlog and the continuing omicron wave."

Scobie added that there was a risk in setting targets now. "The fall in covid cases seems to have stalled in the past few days, and it is not clear what will happen as plan $B$ restrictions are lifted. There are also a lot of geographical differences, with higher rates in Yorkshire and the North East, so a blanket set of targets could be challenging."

Richard Murray, chief executive of the King's Fund, told The BMJ, "There is always a push from the Treasury to make sure they are getting value for money. The risk is when it goes too far and the NHS gets pushed into signing up for targets that they are not going to be able to meet.

"The NHS is still facing very high demand, and we don't really know what happened to the people who disappeared out of the system during the pandemic."

In December the National Audit Office warned that the number of people on the waiting list for elective care in England could reach 12 million by early 2025 without extra staff and bed capacity. ${ }^{3} 4$ In January the House of Commons Health and Social Care Committee warned that reducing the backlog would rely largely on tackling the staffing crisis. ${ }^{5} 6$
"Without tackling the workforce issue, trying to impose targets on the NHS risks being magical thinking," warned Murray.

Scobie agreed, saying, "Staffing issues are critical. No amount of extra physical capacity is sustainable unless the staffing issues are thought through. Mandatory vaccinations of NHS workers could also have a further impact on staff capacity."

With high levels of the omicron variant still circulating, staff sickness is adding to NHS pressures. Although staff absence rates have improved slightly, the NHS still had more than 77 ooo staff absent because of sickness each day in the week to 16 January, 20000 more than at the start of December.

Chaand Nagpaul, BMA council chair, said, "The nation is facing a backlog of care that has placed the NHS under pressure never experienced before. Staff are already exhausted after working flat out for nearly two years of the pandemic and without seeing respite or an end in sight."

Neil Mortensen, president of the Royal College of Surgeons of England, told The BMJ, "There are still huge pressures on hospital capacity, which make it hard to increase levels of planned surgery. We need to use the investment that's been promised to establish surgical hubs in every part of the country."

He added, “And we need a realistic plan that ensures those in the most urgent need are seen first but also doesn't leave those with chronic problems waiting indefinitely. Even if the answer is that it will take five years, we do need to agree a longer term ambition for restoring the current waiting time standard of 18 weeks."

A Department of Health and Social Care spokesperson commented, "The pandemic has put enormous pressures on the NHS, but we are committed to making sure people get the treatment they need.

"We have provided an additional $£ 5.9 \mathrm{bn}$ to help tackle the covid backlogs, and we are investing $€ 36 \mathrm{bn}$ over three years. The elective recovery plan is an important part of our recovery, and we will set out the details in due course."

NHS England. Statistical work areas. https://www.england.nhs.uk/statistics/statistical-work-areas.

2 Campbell D. Ministers and NHS bosses clash over surgery waiting list targets in England. Guardian. Jan 2022. https://www.theguardian.com/society/2022/jan/20/ministers-and-nhs-bosses-clash-over-surgery-waitinglist-targets-in-england

3 lacobucci G. Elective care backlog could rise to 12 million patients by 2025 , warns watchdog. BMJ2021;375:n2977. doi: 10.1136/bmj.n2977 pmid: 34853056

4 National Audit Office, Department of Health and Social Care, NHS England and NHS Improvement. NHS backlogs and waiting times in England. Dec 2021. https://www.nao.org.uk/wp-content/uploads/2021/07/NHS-backlogsand-waiting-times-in-England.pdf.

5 House of Commons Health and Social Care Committee. Clearing the backlog caused by the pandemic. 6 Jan 2022. https://committees.parliament.uk/committee/81/health-and-social-care-committee. 
6 Mahase E. Address staffing crisis to tackle waiting list backlog, say MPs. BMJ 2022;376:013. doi: 10.1136/bmj.013 pmid: 34992081

This article is made freely available for personal use in accordance with BMJ's website terms and conditions for the duration of the covid-19 pandemic or until otherwise determined by BMJ. You may download and print the article for any lawful, non-commercial purpose (including text and data mining) provided that all copyright notices and trade marks are retained. 